\title{
INTERPRETING SENSORY DATA OF CHEESE "KREMA" BY PRINCIPAL COMPONENT ANALYSIS
}

\author{
Miroslav Vasilev, Ira Taneva, Margarita Velikova, Ralitsa Mihova \\ Trakia University, Faculty of Technics and Technologies \\ 38 Graf Ignatiev str., 8602, Yambol, Bulgaria, e-mail: ira_64@abv.bg
}

\begin{abstract}
The report presents results of an analysis of data from an organoleptic evaluation of cheese Krema". For the processing of the results is used "Principal component analysis". The organoleptic data are analyzed for $1^{s t} 15^{\text {th }}$ and the $30^{\text {th }}$ day of storage. For quality evaluation of cheese "Krema" are used the methods of sensory analysis and physico-chemical methods. The sensor analysis is applied in order to measure, analyze and interpret the specific characteristics of the cheese "Krema" that are perceived by the senses, vision, taste and smell. The influence is studied of the storage period on the organoleptic characteristics of the dairy product.
\end{abstract}

Keywords: Cheese "Krema", Organoleptic evaluation, Principal component analysis.

\section{INTRODUCTION}

Cheese "Krema" is produced from whole or skimmed cow's milk and cream with fat content of $25-30 \%$. The original mixture has a fat content of 12 to $12,5 \%$. The cheese is produced on the basis of acid-thermal coagulation. Under the action of the milk fat, which is formed during the fermentation of the milk sugar of lactic acid and aroma forming bacteria overcomes the capacity of the buffer action of the proteins, the active acidity is lowered near the isoelectric point of the coagulation of casein. As a result, at $21-22^{\circ} \mathrm{C}$ occurs coagulation. The oil part remains on the structure of coagulum $[2,5]$.

The cheese "Krema" is often spread on bread, bagels, crackers, etc., and used as a dip for potato chips and similar snack items, and in salads. It can be mixed with other ingredients to make spreads, such as yogurt-cream spread (five parts cream cheese, four part yogurt, whipped). Cheese "Krema" can be used for many purposes in sweet and savoury cookery, and is in the same family of ingredients as other milk products, such as cream, milk, butter, and yogurt. It can be used in cooking to make cheesecake and to thicken sauces and make them creamy. Cheese "Krema" is sometimes used in place of or with butter (typically two parts cream cheese to one part butter) when making cakes or cookies, and cream cheese frosting. It is the main ingredient in the filling of crab rangoon, an appetizer commonly served at U.S. Chinese restaurants. It can also be used instead of butter or olive oil in mashed potatoes and in some western-style sushi rolls $[1,10,11]$.

For quality evaluation of cheese "Krema" are used the methods of sensory analysis and physico-chemical methods. The sensor analysis is applied in order to measure, analyze and interpret the specific characteristics of the cheese "Krema" that are perceived by the senses, vision, taste and smell. As a result of organoleptic analysis gives a quantitative assessment of user quality of cheese "Krema." Organoleptic assessments used in sensory analysis are the averages of the data in the sensor panel $[1,3,8,9,12]$.

The sensor analysis differs significantly from physico-chemical methods in its fast, accurate, but subjective nature. By means physico-chemical methods identify indicators such as moisture content, $\mathrm{pH}$, fat content, acidity and proteins that give us information on the quality of cheese "Krema". The results of the physical and chemical research is a valuable addition to sensory evaluation. The suitability of the instrumental methods should be evaluated on the basis of the results of sensory evaluations obtained by a commission consisting of tasters.

IRTIII Vol. 4, No. 2, 2016 ISSN 1314-8788 (print), ISSN 1314-8796 (online), doi: 10.15547/artte.2016.02.007 


\section{ARTTIE Y}

Ipplied Reseitrones in Technics, Technologies and Bductition

Journal of the Faculty of Technics and Technologies, Trakia University https://sites.google.com/a/trakia-uni.bg/artte/

The purpose of this study is to perform principal component analysis of sensory data of cheese "Krema".

\section{MATERIAL AND METHODS}

To conduct the study were purchased commercially, seven cheeses "Krema" from different manufacturers. Samples were stored for 30 days under refrigeration conditions at $0-5^{\circ} \mathrm{C}[1$, 4]. For the studied cheeses are identified: Moisture content,\% - BNS 1109-89; Active acidity - Used potentiometric pH meter (Model MS 2011, Microsyst, Plovdiv, Bulgaria), equipped with an electrode ( $\mathrm{pH}$ electrode Sensorex, Garden Grove, CA, USA); Fat content,\% - by Gerber in accordance with ISO 2446 (ISO2446, 2008); Titratable acidity - BNS 1111-80; Proteins - by Kjeldahl, \% (BNS EN ISO 5983-1: 2005); Organoleptic analysis - performed by five-point scale, rated are: Butter flavor, Graininess, Sour taste, Fatty after taste, Compactness.In the organoleptic analysis participate sensor panel of nine panelists who are not separated by gender and age. The results of organoleptic analysis are treated with Matlab software and method "Principal component analysis (PCA)" [5, 6, 7, 8, 12].

\section{RESULTS AND DiSCUSSION}

Table 1 shows the mean values of some physico-chemical parameters defined in 1, 15 and 30 days in researched storage period. From the data it is seen that by increasing the duration of storage of samples of cheese "Krema", the moisture content is reduced and the amount of protein in them, while the acidity was increased insignificantly. The changes in the physicochemical indicators define and the organoleptic evaluations of the analyzed samples of cheese "Krema."

Table 1. Physico-chemical parameters of cheese "Krema"

\begin{tabular}{|c|c|c|c|c|c|c|}
\hline \multicolumn{2}{|c|}{$\begin{array}{l}\text { Parameter } \\
\text { Day/ Sample }\end{array}$} & $\begin{array}{c}\text { Water } \\
\text { content, \% }\end{array}$ & pH & $\begin{array}{c}\text { Fat } \\
\text { content, } \%\end{array}$ & Acidity, \% & Protein, \% \\
\hline \multirow{7}{*}{ day 1} & S1 & 56,50 & 5,00 & 12,00 & 1,46 & 7,12 \\
\hline & S2 & 57,50 & 5,00 & 11,68 & 1,45 & 7,12 \\
\hline & S3 & 57,10 & 5,00 & 11,56 & 1,43 & 7,30 \\
\hline & S4 & 57,20 & 5,00 & 11,55 & 1,42 & 7,50 \\
\hline & S5 & 57,30 & 5,00 & 11,35 & 1,51 & 7,60 \\
\hline & S6 & 56,60 & 5,00 & 11,28 & 1,49 & 7,15 \\
\hline & S7 & 57,80 & 5,00 & 11,25 & 1,48 & 7,65 \\
\hline \multirow{7}{*}{ day 15} & S1 & 55,10 & 5,00 & 12,10 & 1,61 & 6,85 \\
\hline & S2 & 56,15 & 5,00 & 11,69 & 1,61 & 6,81 \\
\hline & S3 & 56,12 & 4,00 & 11,60 & 1,65 & 6,98 \\
\hline & S4 & 56,10 & 4,00 & 11,62 & 1,63 & 6,92 \\
\hline & S5 & 55,15 & 5,00 & 11,52 & 1,68 & 6,95 \\
\hline & S6 & 55,10 & 4,00 & 11,38 & 1,58 & 7,05 \\
\hline & S7 & 55,65 & 5,00 & 11,35 & 1,63 & 6,98 \\
\hline \multirow{7}{*}{ day 30} & S1 & 51,85 & 4,00 & 12,20 & 1,70 & 5,01 \\
\hline & S2 & 53,40 & 4,00 & 11,85 & 1,69 & 5,02 \\
\hline & S3 & 52,90 & 4,00 & 11,84 & 1,68 & 5,08 \\
\hline & S4 & 52,89 & 4,00 & 11,82 & 1,71 & 5,07 \\
\hline & S5 & 52,78 & 4,00 & 11,85 & 1,69 & 5,05 \\
\hline & S6 & 51,80 & 4,00 & 11,90 & 1,65 & 5,01 \\
\hline & S7 & 52,60 & 5,00 & 11,50 & 1,69 & 5,02 \\
\hline
\end{tabular}




\section{IRTITE}

In Table 2 are shown the mean values of the assessments of organoleptic evaluation of the studied cheese "Krema". It is seen that with increasing duration of storage for samples 1, 2, 3, 4 and 6 increases organoleptic evaluation of butter flavor, consistency, sour taste and graininess. For samples 5 and 7 for the same period of storage are observed decreased the organoleptic assessments in these indicators.

Table 2. Mean values of organoleptic indicators of cheese "Crema"

\begin{tabular}{|c|c|c|c|c|c|c|}
\hline \multicolumn{2}{|c|}{$\begin{array}{l}\text { Parameter } \\
\text { Day/ Sample }\end{array}$} & $\begin{array}{l}\text { Butter } \\
\text { flavor }\end{array}$ & Graininess & Sour taste & Fatty after taste & Compactness \\
\hline \multirow{7}{*}{ day 1} & $\mathrm{~s} 1$ & 1,90 & 2,80 & 2,90 & 3,20 & 0,95 \\
\hline & s2 & 2,90 & 3,90 & 2,80 & 4,55 & 1,90 \\
\hline & s3 & 3,10 & 3,70 & 3,90 & 4,10 & 1,90 \\
\hline & s4 & 1,90 & 4,00 & 4,00 & 3,30 & 1,80 \\
\hline & s5 & 3,90 & 1,90 & 3,90 & 3,30 & 2,90 \\
\hline & s6 & 4,00 & 1,80 & 3,90 & 3,80 & 3,80 \\
\hline & s7 & 2,60 & 2,70 & 2,80 & 4,30 & 3,20 \\
\hline \multirow{7}{*}{ day 15} & s1 & 2,80 & 3,45 & 3,40 & 3,10 & 1,95 \\
\hline & s2 & 3,20 & 4,50 & 3,20 & 4,30 & 2,20 \\
\hline & s3 & 3,50 & 4,80 & 4,20 & 4,30 & 2,70 \\
\hline & s4 & 2,50 & 4,70 & 4,60 & 4,70 & 2,40 \\
\hline & s5 & 4,90 & 2,95 & 4,80 & 4,90 & 3,30 \\
\hline & s6 & 4,90 & 3,20 & 4,50 & 4,20 & 4,30 \\
\hline & s7 & 4,30 & 3,90 & 4,80 & 4,20 & 3,70 \\
\hline \multirow{7}{*}{ day 30} & s1 & 3,15 & 4,20 & 3,85 & 3,15 & 2,80 \\
\hline & s2 & 3,60 & 4,90 & 3,50 & 4,80 & 2,50 \\
\hline & s3 & 3,90 & 4,80 & 4,70 & 4,90 & 3,30 \\
\hline & s4 & 2,70 & 4,90 & 4,70 & 4,90 & 2,60 \\
\hline & s5 & 4,90 & 3,70 & 4,90 & 3,30 & 3,70 \\
\hline & s6 & 4,90 & 3,30 & 4,90 & 4,50 & 4,60 \\
\hline & s7 & 3,70 & 4,70 & 4,10 & 4,70 & 3,70 \\
\hline
\end{tabular}

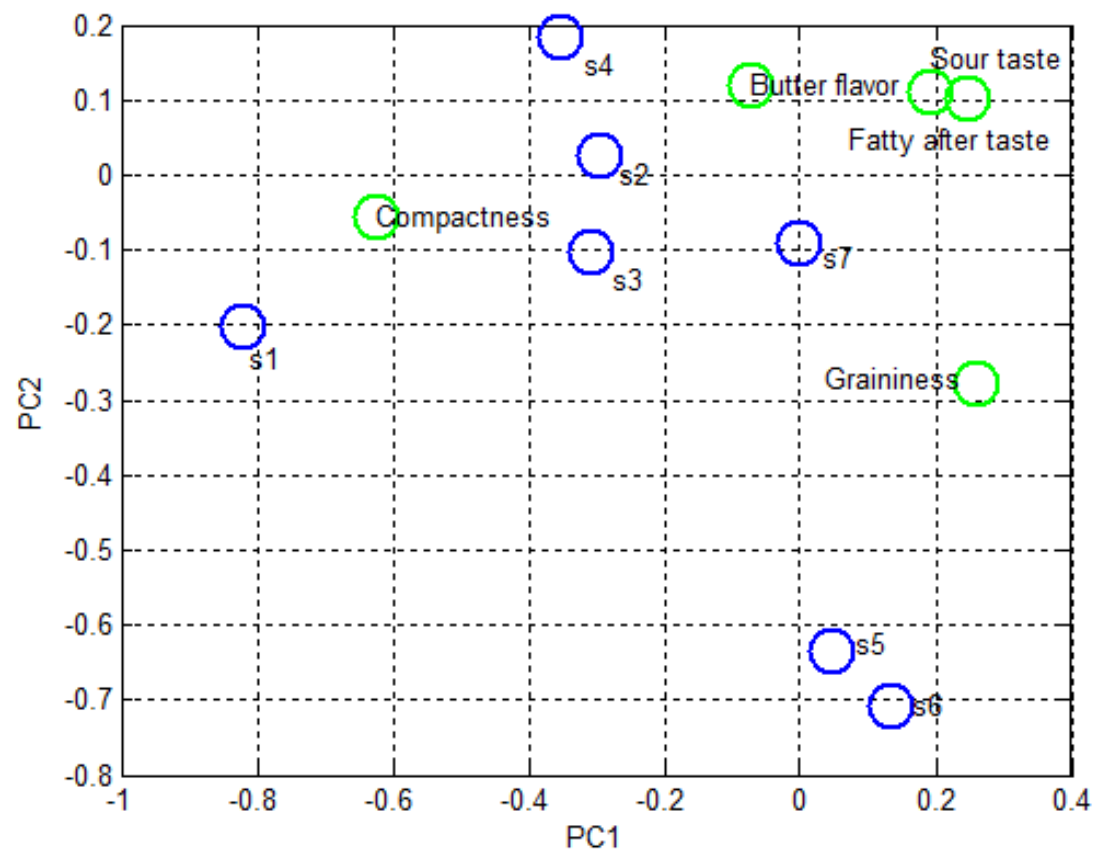

Figure 1. Results for day 1

IRTIIE Vol. 4, No. 2, 2016 ISSN 1314-8788 (print), ISSN 1314-8796 (online), doi: 10.15547/artte.2016.02.007 


\section{IRTITE

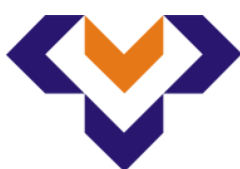

Ipplied Reseitrones in Technics, Technologies and Bductition

Journal of the Faculty of Technics and Technologies, Trakia University https://sites.google.com/a/trakia-uni.bg/artte/

Figure 1 presents the results of analysis of samples of organoleptic evaluation on the first day of storage. The data shows that sample 2 has the best indicators fatty aftertaste and samples 5 and 6 are far from the indicators. The remaining samples 3,4 and 7, have good Butter flavor, Graininess, Fatty after taste, Sample 1, according to data analysis is with degraded organoleptic indicators.

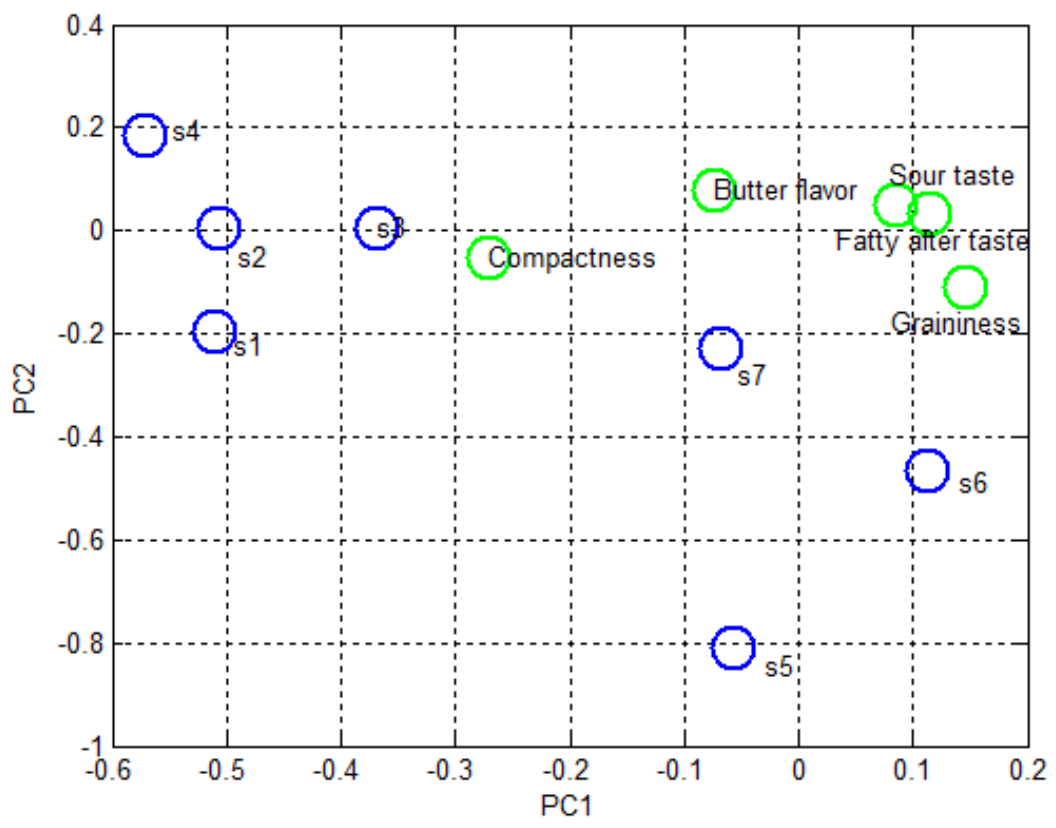

Figure 2. Results for day 15

Figure 2 presents the results of analysis of samples of organoleptic evaluation in the fifteenth day of storage. According to the analysis of samples 6 and 7 have the best indicators of graininess and butter flavor. The remaining samples are with deteriorated organoleptic indicators.

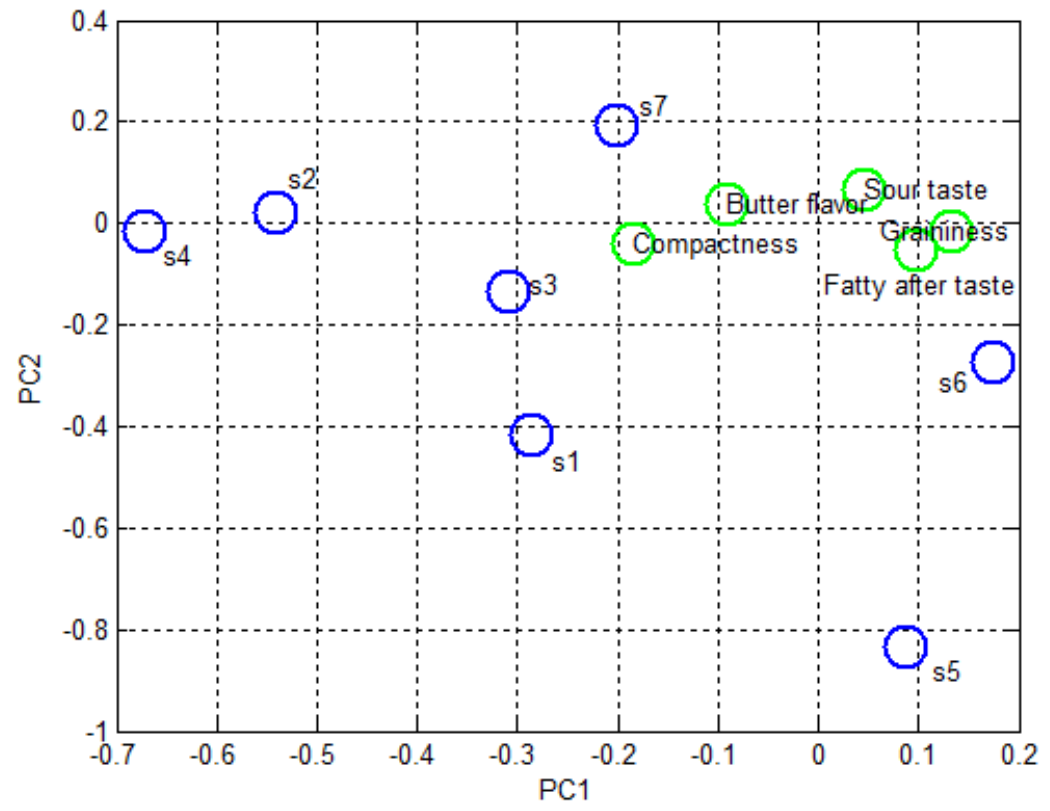

Figure 3. Results for day 30

IRT'TIE Vol. 4, No. 2, 2016 ISSN 1314-8788 (print), ISSN 1314-8796 (online), doi: 10.15547/artte.2016.02.007 


\section{ARTITE

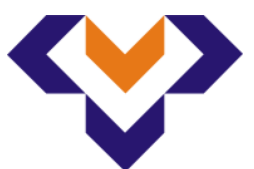 \\ Ipplied Reseitrones in Technics, Technologies and Bductition \\ Journal of the Faculty of Technics and Technologies, Trakia University https://sites.google.com/a/trakia-uni.bg/artte/}

In analyzing the samples in the thirtieth day of their storage at all there is a minor change in the organoleptic indicators. There is a slight increase in sour taste in the samples the most significant it was observed in first sample. The data of the results are presented in Figure 3. The sour taste is slightly increased for the samples 1, 3, 6 and 7.

The data shows that in the first day of storage of samples, all have high values of indicator fatty aftertaste. With increasing the storage time in the fifteenth and thirtieth day of storage, there is increasing performance butter flavor, compactness and graininess of the samples.

\section{CONCLUSION}

The analysis of the results of the study can be concluded as follows:

$\checkmark$ It has been used method "Principal component analysis" for evaluation of sensory characteristics of cheese "Krema".

$\checkmark$ The influence is evaluated of the storage period on the organoleptic characteristics of the dairy product and the results show that with increasing the storage time in the fifteenth and thirtieth day of storage, there is increasing performance butter flavor, compactness and graininess of the samples.

$\checkmark \quad$ In subsequent studies can be made analyzes based on the data referred to by the tasters and implement other methods of analysis as "Correspondence analysis", "Analysis of variance", "Multi-factor analysis".

\section{ACKNOWLEDGEMENTS}

The work in this report is related to the research project of Faculty of Technics and Technologies of Yambol, Trakia University, Bulgaria 3.FTT/ 30.05.2016 "Contactless methods for evaluation of main quality characteristics of dairy products".

\section{REFERENCES}

[1] Baltadjieva M., Technology of dairy products, Sofia, Zemizdat, 1993 (in Bulgarian).

[2] BNS 9205:1977/changed 3:1990 "Cheese Crema“.

[3] Boneva P., V. Bonev, H. Beloev, N. Orloev, VIEDA - game-based education system, 7th International Conference on Education and New Learning Technologies, 6-8 July, 2015, Barcelona, Spain, EDULEARN15 Proceedings, ISSN: 2340-1117, pp.2555-2561.

[4] Georgieva, K., Ts. Georgieva, E. Kirilova, P. Daskalov. Classification of healthy and diseased vine leaves using color features. ARTTE, Vol. 3, No. 4, 2015, ISSN 1314-8796, pp.296-302.

[5] Gulzar N., A. Sameen, M. Khan, N.Huma, M. Murtaza, S. Rafiq, Nutritional and functional properties of fruited cream cheese spread as influenced by hydrocolloids, Journal of Food and Nutrition Research, Vol.3, No.3, 2015, ISSN 2333-1240, pp.191195.

[6] Kazlacheva Z., Using correspondence analysis in fashion design, Textile and apparel, vol.7, 2011, ISSN 1310-912X, pp.191-196 (in Bulgarian).

[7] Mladenov M., S. Penchev, M. Deyanov, Complex assessment of food products quality using analysis of visual images, spectrophotometric and hyperspectral characteristics. International Journal of Engineering and Innovative Technology (IJEIT), Vol. 4, Iss. 12, 2015, ISSN: 2277-3754, pp.23-32.

[8] Nedeva, V., Z. Zlatev, S. Atanasov, Effective Resources Use for Virtual Laboratories through Cloud Computing and Services. In ICVL 2012, The 7th International Conference on Virtual Learning, pp.322-328.

IRTIIE Vol. 4, No. 2, 2016 ISSN 1314-8788 (print), ISSN 1314-8796 (online), doi: 10.15547/artte.2016.02.007 


\section{ARTTIE $Y$}

Ipplied Researlohes in Technics, Technologies and Bductition Journal of the Faculty of Technics and Technologies, Trakia University https://sites.google.com/a/trakia-uni.bg/artte/

[9] Simeonov M., H. Ibrishimov, P. Prodanov "Modeling and analysis of an inductor - piece system with differentiated domains of the electromagnetic field in the inductor" PCIM Europe 2013, Paper No PP17, Nurnberg, Germany, 13-15 May 2013, pp.1-5.

[10] Tasev G., K. Krastev, Exploration of mathematical model for optimization of frequency of diagnosis of the elements of machines, Proceedings of The 11th International Conference, Reliability and statistics in transportation and communication, Latvia, 2011, ISBN 978-9984-818-34-4, pp.115-119.

[11] The story, found in numerous cheese histories, that Lawrence "accidentally" made cream cheese or had stolen the recipe from another Chester dairyman, Charles Green, is a fabrication. Jeffrey A. Marx, "The Days Had Come of Curds and Cream": The Origins and Development of Cream Cheese in America, in Journal of Food, Culture and Society, Vol. 15, Issue 2, June 2012.

[12] Zlatev Z., I. Penchev, S. Ribarski, S. Baycheva, Analysis of sensory data of perishable boiledsmoked sausages, Innovation and entrepreneurship - Applied scientific journal, Vol.4, No.3, 2016, ISSN 1314-9253, pp.3-15. 